\title{
PENCEGAHAN DAN PENANGGULANGAN PENYEBARAN COVID 19 PADA ANAK-ANAK DENGAN CARA 4M
}

\author{
Puspita Ayu Marhaeni, Beti Prihandini, Sulastri, Ni Nyoman Yeni dan Ria Setia \\ Sari \\ STIKes Yatsi Tanggerang Banten, Indonesia \\ Email: puspita.kanza@gmail.com, betiprihandini@gmail.com, tris2597@gmail.com, \\ nyoman.yeni@gmail.com, riasetia233@gmail.com,
}

\begin{abstract}
The purpose of this community service is so that parents and children can understand the prevention and control of the spread of COVID-19 in children while utilizing $4 M$ movements (washing hands, wearing masks, maintaining distance, avoiding crowds in the Indonesian language). The method used is health education and the practice of six steps to washing your hands. The results of this activity showed that children could understand and be interested in participating in health education on "prevention and control of the spread of COVID-19 to children by using 4M movements", and children and families are willing to implement protocols in their lives. The conclusion is that by implementing the $4 M$ protocol in the family environment, we hope it can reduce the spread of COVID-19 in Indonesia.
\end{abstract}

Keywords: COVID-19, pandemic; 4M; washing hands; wearing masks; maintaining distance; avoidingcrowds

\begin{abstract}
Abstrak
Tujuan dari pengabdian masyarakat ini adalah agar orang tua dan anak-anak dapat memahami tentang pencegahan dan penanggulangan penyebaran COVID-19 pada anak-anak dengan cara 4M (mencuci tangan, memakai masker, menjaga jarak, menghindari kerumunan). Metode yang digunakan adalah pendidikan kesehatan dan praktik 6 langkah cuci tangan. Hasil dari kegiatan ini menunjukkan bahwa anak-anak mampu memahami dan antusias dalam mengikuti pendidikan kesehatan tentang "pencegahan dan penanggulangan penyebaran COVID-19 pada anak-anak dengan cara 4M" serta anak-anak dan keluarga mau untuk melaksanakan protokol disetiap kehidupannya. Kesimpulan yang bisa diambil adalah dengan melaksanakan protokol 4M dilingkungan keluarga diharapkan dapat menekan angka penyebaran COVID-19 di Indonesia.
\end{abstract}

Kata kunci: COVID-19; pandemik; 4M; mencuci tangan; memakai masker; menjaga jarak; menghindari kerumunan

Coresponden Author

Email: puspita.kanza@gmail.com Artikel dengan akses terbuka dibawah lisensi 


\section{Pendahuluan}

Pada awal maret 2020, dunia dikejutkan oleh munculnya pandemi covid 19 yang merubah hampir seluruh sistem tatanan kehidupan manusia. organisasi kesehatan dunia (WHO) secara resmi menyatakan bahwa covid 19 menjadi pandemik global dan meminta ke semua negara untuk melakukan upaya maksimal dalam guna membatasi penyebaran maupun jumlah kasus covid 19. dalam kondisi saat ini, virus corona bukanlah suatu wabah yang bisa diabaikan begitu saja (Harahap, 2020).

Terhitung mulai tanggal 19 Maret 2020 sebanyak 214.894 orang terinfeksi virus corona, 8.732 orang meninggal dunia dan pasien yang telah sembuh sebanyak 83.313 orang. Khusus di Indonesia sendiri Pemerintah telah mengeluarkan status darurat bencana terhitung mulai tanggal 29 Februari 2020 hingga 29 Mei 2020 terkait pandemi virus ini dengan jumlah waktu 91 hari (Sumantri, Triana, \& Buhana, 2021).

Peningkatan jumlah kasus corona terjadi dalam waktu singkat dan membutuhkan penanganan segera. Virus corona dapat dengan mudah menyebar dan menginfeksi siapapun tanpa pandang usia. Virus ini dapat menular secara mudah melalui kontak dengan penderita (Mona, 2020).

Pandemik Covid-19 mempunyai dampak yang sangat luas di berbagai sektor. Indonesia saat ini dihadapkan pada situasi sulit terkait dengan penanganan dampak pandemik covid-19, usaha-uasaha yang dilakukan terkait dengan upaya untuk menekan angka kematian penduduk yang terinfeksi virus covid-19, maupun upaya untuk menangani dampak sosial ekonomi dari penyebaran virus (Kresna \& Ahyar, 2020).

Corona virus merupakan virus jenis baru yang kini telah menggemparkan masyarakat dunia (Mona, 2020). Masalahnya virus ini telah berhasil menginfeksi ribuan juta masyarakat global dalam waktu yang sangat singkat (Li, Wang, Xue, Zhao, \& Zhu, 2020). Bahkan manusia tanpa menunjukkan gejala terinfeksi. Bahkan manusia tanpa menunjukkan gejala terinfeksi Corona virus dapat pula menyebarkan kepada manusia lainnya (Kumar \& Dwivedi, 2020).

Severe acute respiratory syndrome coronavirus 2 (SARS-CoV-2) yang lebih dikenal dengan nama virus corona adalah jenis baru dari coronavirus yang menular ke manusia. Virus tersebut dapat menyerang siapapun, baik bayi, anak-anak, dewasa, lansia, ibu hamil, maupun ibu menyusui. Infeksi virus ini telah diberi nama oleh WHO Analisis Pengaruh Social Distancingdalam Pencegahan Penyebaran Virus Corona untuk penyakit tersebut yaitu COVID -19 sertapertama kali ditemukan di kota Wuhan, Cina, pada akhir Desember 2019 (Santosa, 2020).Peningkatan jumlah kasus corona terjadi dalam waktu singkat dan membutuhkan penanganan segera. Virus corona dapat dengan mudah menyebar dan menginfeksi siapapun tanpa pandang usia. Virus ini dapat menular secara mudah melalui kontak dengan penderita.

Saat ini bangsa indonesia sedang menghadapi tantangan yang mengharuskan sumber daya manusia beradaptasi dengan situasi pandemi corona virus disease 2019 (covid-19) jika dilihat dari gejalanya, orang awam akan mengiranya hanya sebatas 
influenza biasa, tetapi bagi analisis kedokteran virus ini cukup berbahaya dan mematikan (Chan et al., 2020) mengantisipasi dan mengurangi jumlah penderita virus corona di indonesia sudah dilakukan di seluruh daerah. diantaranya dengan memberikan kebijakan membatasi aktifitas keluar rumah, kegiatan sekolah dirumahkan, bekerja dari rumah (work from home) (Quyumi, E., \& Alimansur, 2020) hal ini sudah menjadi kebijakan pemerintah berdasarkan pertimbangan-pertimbangan yang sudah dianalisa dengan maksimal tentunya. kebijakan ini diharapkan mampu mengatasi masalah yang terjadi di masyarakat. kebijakan ini ditetapkan oleh beberapa pihak terutama pemerintah yang diorientasikan pada pemenuhan kebutuhan dan kepentingan masyarakat (Peraturan Menteri Kesehatan Republik Indonesia, 2019).

Protokol Kesehatan untuk penanggulangan COVID-19 terdiri dari fase pencegahan, fase deteksi dan fase respon (Badan Keahlian D. P. R. RI, Lt, \& Subroto, 2020). Peran dari masyarakat dalam setiap fase sangat dibutuhkan untuk menghindari terjadinya penularan yang lebih banyak. Pemerintah telah mengeluarkan pedoman kesiapsiagaan dalam menghadapi penyebaran COVID-19. Upaya yang dapat dilakukan pada fase pencegahan oleh setiap individu antara lain: Memakai masker, Memakai sarung tangan, Menggunakan hand sanitizer/desinfektan, Mencuci tangan dengan sabun, Menghindari menyentuh wajah, Menghindari berjabat tagan, Menghindari pertemuan atau antrian Panjang, Menghindari menyentuh benda/permukaan benda di area publik, Menghindari naik transportasi umum, Menjaga jarak setidaknya dua meter dari orang lain ketika di luar rumah, dan Jika menunjukkan gejala penyakit segera memberi tahu orang-orang di sekitar (Kemenkes RI, 2020).

kesadaran masyarakat untuk menjaga kebersihan dan kebugaran tubuh harus ditingkatkan beberapa upaya untuk mencegah penularan covid-19 yaitu : sering mencuci tangan dengan sabun atau cairan antiseptik, menerapkan etika batuk dan bersin dengan benar menghindari menyentuh wajah dengan tangan, menjaga jarak dan mengenakan masker, serta melakukan aktivitas di dalam rumah (menghindari kerumunan) yang diajarkan sejak usia anak-anak. dari gambaran ini maka kelompok terarik untuk melakukan pengabdian masyarakat dengan memberikan pendidikan kesehatan pencegahan dan penanggulangan penyebaran covid 19 pada anak-anak dengan cara 4M (Setiati \& Azwar, 2020) tujuan dari kegiatan ini supaya orang tua dan anak-anak dapat memahami tentang pencegahan dan penanggulangan penyebaran covid 19 pada anakanak dengan cara 4M dengan harapan dapat menekan angka kejadian covid19 di Indonesia.

Skema WFH merupakan bagian dari konsep telecommuting(bekerja jarak jauh)2, yang sebenarnya bukan hal baru dalam dunia kerja dan perencanaan kota, bahkan telah dikenal sejak tahun 1970-an sebagai salah satu upaya mengatasi kemacetan lalulintas dariperjalanan rumah-kantor pulang-pergi setiap hari (Mungkasa, 2020).

Penelitian terdahulu yang sudah dilakukan oleh (Darmalaksana, Hambali, Masrur, \& Muhlas, 2020) tentang analisis pembelajaran online masa WFH Pandemik Covid-19 sebagai tantangan pemimpin digital abad 21. Sehingga dengan melihat fenomena diatas mendorong peneliti untuk melakukan penelitian dengan tujuan untuk menganalisi 
tentang pelaksanaan aktivitas belajar daring mahasiswa pada masa tanggap darurat COVID-19.

\section{Metode Penelitian}

Metode yang digunakan adalah pendidikan kesehatan dan praktik 6 langkah cuci tangan. Output yang ada dalam penelitian adalah modifikasi pola hidup di situasi pandemi covid 19. Berdasarkan pada kemampuan anak-anak, keluarga serta masyarakat untuk melaksanakan protokol 4M (mencuci tangan, memakai masker, menjaga jarak, menghindari kerumunan). Penelitian dengan melakukan survey dan mencari informasi yang berkaitan dengan penelitian. Berdasarkan hasil observasi tersebut peneliti mengidentifikasi dan merumuskan permasalahan yang ada di lapangan yaitu: kebiasaan / pola hidup di masyarakat selama pandemic covid 19. Selanjutnya peneliti menentukan perlengkapan yang dibutuhkan oleh masyarakat untuk dapat melakukan perubahan modifikasi pola hidup selama pandemic covid 19.

\section{Hasil dan Pembahasan}

Kegiatan Pengabdian Masyarakat mengenai "pencegahan dan penanggulangan penyebaran covid 19 pada anak-anak dengan cara 4M" kepada orangtua dan anak- anak. ini telah selesai dilaksanakan dalam satu kali pertemuan. Kegiatan dilaksanakan dirumah masing-masing keluarga yang menjadi peserta kegiatan pada tgl 25 januari 2021 jam 15.00 WIB s/d selesai. Jumlah peserta 15 orang. Setelah dilakukan evaluasi, anak-anak mampu memahami dan antusias dalam mengikuti pendidikan kesehatan tentang "pencegahan dan penanggulangan penyebaran covid 19 pada anak-anak dengan cara 4M" serta mempraktekkan 6 langkah mencuci tangan dengan baik, anak-anak mampu menjawab pertanyaan yang diberikan mengenai pentingnya $4 \mathrm{M}$ (mencuci tangan, memakai masker, menjaga jarak, menghindari kerumunan) dan mempraktekan kembali 6 langkah cuci tangan. Keberhasilan kegiatan ini dapat dilihat dari diikutinya program $4 \mathrm{M}$ (mencuci tangan, memakai masker, menjaga jarak, menghindari kerumunan) dan anak dapat mempraktekkan kembali 6 langkah cuci tangan dengan hand sanitizer oleh seluruh anak- anak dan keluarga yang menjadi peserta dalam pengabdian masyarakat ini. Kegiatan penyuluhan program $4 \mathrm{M}$ ini mendapatkan bantuan dari mahasiswa berupa peralatan mencuci tangan, masker. Sehingga kegiatan penyuluhan program $4 \mathrm{M}$ dapat terlaksana dengan baik.

\section{Kesimpulan}

Berdasarkan hasil kegiatan pengabdian masyarakat "pencegahan dan penanggulangan penyebaran covid 19 pada anak-anak dengan cara 4M" yang telah dilakukan dilingkungan tempat tinggal sekitar mahasiwa. Peserta pada anak usia 0 -18 th beserta keluarga yang mendampingi. dapat disimpulkan bahwa kegiatan yang dilakukan berjalan dengan lancar dan sesuai dengan yangdiharapkan. 
Kegiatan ini diikuti oleh seluruh anak usia 0-18 th dilingkungan tempat tinggal sekitar mahasiwa. Hasil evaluasi kegiatan menunjukkan anak-anak mampu memahami dan antusias dalam mengikuti pendidikan kesehatan tentang "pencegahan dan penanggulangan penyebaran covid 19 pada anak-anak dengan cara 4M" serta mempraktekkan 6 langkah mencuci tangan dengan baik, anak-anak mampu menjawab pertanyaan yang diberikan mengenai pentingnya $4 \mathrm{M}$ (mencuci tangan, memakai masker, menjaga jarak, menghindari kerumunan) dan mempraktekan kembali 6 langkah cuci tangan.

Adanya pengabdian masyarakat ini diharapkan pentingnya peran orang tua dalam mendampingi, mengarahkan, mengingatkan serta mengajarkan putra putrinya pentingnya perubahan pola hidup selama pandemik ini dengan menerapkan protokol 4 M. Selain itu juga perlunya motivasi orang tua untuk membudayakan anak agar selalu mencuci tangan pakai sabun sebelum dan sesudah melakukan kegiatan, seperti bermain, makan, buang air kecil dan besar, dan lain-lain. 


\section{BIBLIOGRAFI}

Chan, Jasper Fuk Woo, Yuan, Shuofeng, Kok, Kin Hang, To, Kelvin Kai Wang, Chu, Hin, Yang, Jin, Xing, Fanfan, Liu, Jieling, Yip, Cyril Chik Yan, \& Poon, Rosana Wing Shan. (2020). A familial cluster of pneumonia associated with the 2019 novel coronavirus indicating person-to-person transmission: a study of a family cluster. The Lancet, 395(10223), 514-523.

Darmalaksana, Wahyudin, Hambali, R., Masrur, Ali, \& Muhlas, Muhlas. (2020). Analisis pembelajaran online masa wfh pandemic covid-19 sebagai tantangan pemimpin digital abad 21. Karya Tulis Ilmiah (KTI) Masa Work From Home (WFH) Covid-19 UIN Sunan Gunung Djati Bandung, 1-12.

Harahap, Dinda Andini. (2020). Upaya Memutuskan Rantai Penularan COVID-19. Http://Jurnalrespirologi.Org/Index.Php/Jri/Article/View/101.

Kresna, Arief, \& Ahyar, Juni. (2020). Pengaruh Physical Distancing Dan Social Distancing Terhadap Kesehatan Dalam Pendekatan Linguistik. Jurnal Syntax Transformation, 1(4), 14-19.

Kumar, Mahendra, \& Dwivedi, Sachin. (2020). Impact of coronavirus imposed lockdown on Indian population and their habits. International Journal of Science and Healthcare Research, 5(2), 88-97.

Li, Sijia, Wang, Yilin, Xue, Jia, Zhao, Nan, \& Zhu, Tingshao. (2020). The impact of COVID-19 epidemic declaration on psychological consequences: a study on active Weibo users. International Journal of Environmental Research and Public Health, 17(6), 2032.

Mona, Nailul. (2020). Konsep Isolasi Dalam Jaringan Sosial Untuk Meminimalisasi Efek Contagious (Kasus Penyebaran Virus Corona Di Indonesia). Jurnal Sosial Humaniora Terapan, 2(2).

Mungkasa, Oswar. (2020). Bekerja dari Rumah (Working From Home/WFH): Menuju Tatanan Baru Era Pandemi COVID 19. Jurnal Perencanaan Pembangunan: The Indonesian Journal of Development Planning, 4(2), 126-150.

Peraturan Menteri Kesehatan Republik Indonesia, Nomor 9. (2019). (Pedoman Pembatasan Sosial Berskala Besar dalam Rangka Percepatan Penanganan Corona Virus Disease 2019 (COVID-19). Http://Jurnalrespirologi.Org/Index.Php/Jri/Article/View/101, 2-6.

Quyumi, E., \& Alimansur, M. (2020). Upaya Pencegahan Dengan Kepatuhan Dalam Pencegahan Penularan Covid-19 Pada Relawan Covid. Jph Recode, 4(1), 81-87.

RI, Badan Keahlian D. P. R., Lt, Gd Nusantara I., \& Subroto, Jl Jend Gatot. (2020). Kesiapsiagaan Indonesia Menghadapi Potensi Penyebaran Corona Virus Disease. 
Puspita Ayu Marhaeni, Beti Prihandini, Sulastri, Ni Nyoman Yeni dan Ria Setia Sari

RI, Kemenkes. (2020). Pedoman Pencegahan dan Pengendalian Coronavirus Disease (COVID-19)'. Kemenkes RI, 0-115.

Santosa, Santi Puspa Ariyani. (2020). (2020). Analisis Pengaruh Social Distancing Dalam Pencegahan Penyebaran Virus Corona Dengan Pelaksanaan Sholat Fardhu Berjamaah Di Masjid Al Ikhlas Desa Sukoharjo Kecamatan Margorejo Kabupaten Pati Jawa Tengah. Jurnal Syntax Idea, 2(5).

Setiati, Siti, \& Azwar, Muhammad Khifzhon. (2020). COVID-19 and Indonesia. Acta Medica Indonesiana, 52(1), 84-89.

Sumantri, Asep, Triana, Erni, \& Buhana, Fitri. (2021). Analisis perilaku masyarakat indonesia dalam menghadapi pandemi virus corona (Covid-19) dan kiat menjaga kesejahteraan jiwa. Proceding Secretari Universitas Pamulang, 1(1). 